\title{
Implementasi Metode Analytical Hierarchy Process Dalam Menentukan Kelayakan Guru Penerima Umrah
}

\author{
Yasir Hasan \\ STMIK Budi Darma Medan, JI. SM.Raja No.338 Sp.Limun Medan, Sumut, Indonesia \\ www.stmik-budidarma.ac.id // E-mail : dos.asmbd@gmail.com
}

\begin{abstract}
Umrah means carrying out tawaf in the Ka'bah and sa'i between Shofa and Marwah, after using the inram taken from the miqat. It is often referred to as the small Umrah pilgrimage for teachers every year who have loyalty and other best criteria. The number of hikmatul fadillah foundation teachers often makes the team of selectors confused in determining the best teacher to be given Umrah, because each of the teachers has criteria. Analytical Hierarchy Process (AHP) is a decision support model that will describe multi-factor problems or complex multi criteria into a hierarchy. With hierarchy, a complex problem can be broken down into groups which are then arranged into a hierarchical form so that the problem will appear. more structured and systematic.
\end{abstract}

\section{Kata kunci : Sistem Pendukung Keputusan, Penerima umrah, Analytical Hierarchy Process (AHP).}

\section{PENDAHULUAN}

Umrah adalah salah satu kegiatan ibadah dalam agama Islam. Hampir mirip dengan ibadah haji, ibadah ini dilaksanakan dengan cara melakukan beberapa ritual ibadah di kota suci Mekkah, khususnya di Masjidil Haram. Pada istilah teknis syari'ah, Umrah berarti melaksanakan tawaf di Ka'bah dan sa'i antara Shofa dan Marwah, setelah memakai ihram yang diambil dari miqat. Sering disebut pula dengan haji kecila.3.[10]. Perbedaan umrah dengan haji adalah pada waktu dan tempat. Umrah dapat dilaksanakan sewaktu-waktu (setiap hari, setiap bulan, setiap tahun) dan hanya di Mekkah, sedangkan haji hanya dapat dilaksanakan pada beberapa waktu antara tanggal 8 Dzulhijjah hingga 12 Dzulhijjah serta dilaksanakan sampai ke luar kota Mekkah..

Dalam pemilihan guru untuk menerima umrah, pemilik yayasan mendapat kesulitan dan memerlukan waktu yang lama dalam mengambil keputusan sesuai dengan kriteria yang diinginkan. masalah ini digolongkan kedalam masalah yang bersifat multicriterias (ada banyak kriteria yang menentukan dalam mencapai keputusan tersebut) misalnya Hafal Al-Quran, Menejemen Kelas, Masa Kerja, Loyalitas.

Model yang digunakan dalam sistem pendukung keputusan ini adalah Fuzzy Multiple Attribute Decision Making (FMADM). Metode AHP ini dipilih karena sebagai suatu representasi dari sebuah permasalahan yang kompleks dalam suatu struktur multi level dimana level pertama adalah tujuan, yang diikuti level faktor, kriteria, sub kriteria, dan seterusnya ke bawah hingga level terakhir dari alternatif. Dengan hirarki, suatu masalah yang kompleks dapat diuraikan ke dalam kelompokkelompoknya yang kemudian diatur menjadi suatu bentuk hirarki sehingga permasalahan akan tampak lebih terstruktur dan sistematis. Dalam hal ini alternatif yang dimaksud adalah Guru berdasarkan kriteria-kriteria yang ditentukan. Dengan metode perangkingan tersebut, diharapkan penilaian akan lebih tepat karena didasarkan pada nilai kriteria dan bobot yang sudah ditentukan sehingga akan mendapatkan hasil yang lebih akurat terhadap penentuan guru penerima umraha.3.[7].

\section{LANDASAN TEORI}

\subsection{Sistem Pendukung Keputusan}

Konsep Sistem Pendukung Keputusan pertama kali diungkapkan pada awal tahun 1970-an oleh Michael S. Scott Morton dengan istilah Management Decision Sistem. Sistem tersebut adalah suatu sistem yang berbasis komputer yang ditujukan untuk membantu pengambil keputusan dengan memanfaatkan data dan model tertentu untuk memecahkan berbagai persoalan yang tidak terstruktur.
Istilah SPK mengacu pada suatu sistem yang memanfaatkan dukungan komputer dalam proses pengambilan keputusan. dimana tak seorangpun tahu secara pasti bagaimana keputusan seharusnya dibuat (Turban, 2001).

Sistem Pendukung Keputusan (Desicion Support System) merupakan sistem informasi interaktif yang menyediakan informasi, pemodelan dan pemanipulasi data. Sistem itu digunakan untuk membantu pengambilan keputusan dalam situasi yang semiterstruktur 
dan situasi yang tidak terstruktur, dimana tak seorang pun tahu secara pasti bagaimana keputusan seharusnya dibuata.3.[10].

\subsection{Analytical Hierarchy Process}

Metode AHP(Analytical Hierarchy Process) dikembangkan oleh Thomas L. Saaty, seorang ahli matematika. Metode ini adalah sebuah karangan untuk mengambil keputusan dengan efektif atas persoalan yang kompleks dengan menyederhanakan dan mempercepat proses pengambilan keputusan dengan memecahkan persoalan tersebut kedalam bagian-bagiannya, menata bagian atau variabel ini dalam susunan hirarki, memberi nilai numerik pada pertimbangan subjektif tentang pentingnya setiap variabel dan mensintesis berbagai pertimbangan. Ini untuk menetapkan variabel yang mana memiliki prioritas paling tinggi dan bertindak untuk memiliki hasil pada situasi tertentu a.3.[9]. Metode AHP(Analytical Hierarchy Process)memiliki banyak keunggulan dalam menjelaskan proses pengambilan keputusan. Salah satunya adalah dapat digambarkan secara grafis sehingga mudah dipahami oleh semua pihak yang terlibat dalam pengambilan keputusan. a.3.[4]

Pada dasarnya, prosedur atau langkahlangkah dalam metode AHP (Analytical Hierarchy Process) meliputi:

1. Mendefenisikan masalah dan menentukan solusi yang diinginkan, lalu menyusun hierarki dari permasalahan yang dihadapi. Penyusunan hierarki adalah dengan menetapkan tujuan yang merupakan sasaran sistem secara keseluruhan pada level teratas.

2. Menentukan prioritas elemen

a. Langkah pertama dalam menentukan prioritas elemen adalah membuat perbandingan pasangan, yaitu membandingkan elemen secara berpasangan sesuai kriteria yang diberikan.

b. Matriks perbandingan berpasangan diisi menggunakan bilangan untuk merepresentasikan kepentingan relatif dari suatu elemen terhadap elemen yang lainnya.

3. Sintesis

Pertimbangan-pertimbangan terhadap perbandingan berpasangan disintesis untuk memperoleh keseluruhan prioritas. Hal-hal yang dilakukan dalam langkah ini adalah:

a. Menjumlahkan nilai-nilai dari setiap kolom pada matriks

b. Membagi setiap nilai dari kolom dengan total kolom yang bersangkutan untuk memperoleh normalisasi matriks

c. Menjumlahkan nilai-nilai dari setiap baris dan membaginya dengan jumlah elemen untuk mendapatkan nilai rata-rata

4. Mengukur Konsistensi

Dalam pembuatan keputusan, penting untuk mengetahui seberapa baik konsistensi yang ada karena kita tidak menginginkan keputusan berdasarkan pertimbangan dengan konsistensi yang rendah. Hal-hal yang dilakukan dalam langkah ini adalah:

a. Kalikan setiap nilai pada kolom pertama dengan prioritas relatif elemen pertama, nilai pada kolom kedua dengan prioritas relatif elemen kedua, dan seterusnya

b. Jumlahkan setiap baris

c. Hasil dari penjumlahan baris dibagi dengan elemen prioritas relatif yang bersangkutan

d. Jumlahkan hasil bagi diatas dengan banyaknya elemen yang ada, hasilnya disebut $\wedge$ maks

5. Hitung Consistency Index (Cl) dengan rumus:

$\mathrm{Cl}=(\wedge$ maks $-\mathrm{n}) / \mathrm{n}$

Di mana $n=$ banyaknya elemen

6. Hitung Rasio Konsistensi/Consistency Ratio (CR) dengan rumus:

$\mathrm{CR}=\mathrm{Cl} / \mathrm{RC}$

Di mana $\mathrm{CR}=$ Consistency Ratio $\mathrm{Cl}=$ Consistency Index $\mathrm{IR}=$ Index Random Consistency

7 Memeriksa konsistensi hierarki. Jika nilainya lebih dari $10 \%$, maka penilaian data judgment harus diperbaiki. Namun jika rasio konsistensi (Cl/IR) kurang atau sama dengan 0,1 maka hasil perhitungan bisa dinyatakan benar.

Tabel 1. Daftar Index Random Konsistensi (IR).

\begin{tabular}{|c|l|}
\hline $\begin{array}{c}\text { Ukuran } \\
\text { Matriks }\end{array}$ & Nilai IR \\
\hline 1,2 & 0,00 \\
\hline 3 & 0.58 \\
\hline 4 & 0.90 \\
\hline 5 & 1.12 \\
\hline 6 & 1,24 \\
\hline 7 & 1,32 \\
\hline 8 & 1,41 \\
\hline 9 & 1,45 \\
\hline 10 & 1,49 \\
\hline 11 & 1,51 \\
\hline 12 & 1,48 \\
\hline 13 & 1,56 \\
\hline
\end{tabular}




\section{HASIL DAN PEMBAHASAN}

\subsection{Analisa}

Sebelum menerapkan metode sistem pendukung keputusan penentuan Guru penerima umrah ini, terlebih dahulu harus mendekripsikan masalah-masalah dalam proses pengambilan keputusan. Dari pengamatan dan studi lapangan diketahui bahwa pelaksanaan penentuan guru penerima umrah menemukan beberapa permasalahan, antara lain :

1. Lamanya pelaksanaan dari satu proses ke proses penentuan guru penerima umrah berikutnya karena kendala kesulitan pengolahan data karena masih manual.

2. Kesulitan dalam memberkaskan semua hasil pilihanpenentuan guru penerima umrah dari satu periode, untuk bahan evaluasi periode berikutnya.

3. Kesulitan dalam menyajikan data hasil penentuan guru penerima umrah dalam waktu yang cepat dan transparan.

4. Kesulitan dalam mengambil keputusan untuk penentuan guru penerima umrah karena kurangnya dukungan data dari proses sebelumnya.

\subsection{Penerapan Metode AHP}

Langkah-langkah yang harus dilakukan untuk menentukan guru yang lulus dengan metode Analytical Hierarchy Process (AHP) adalah sebagai berikut :

1. Intelligent.

2. Modelling.

3. Choice.

1. Tahap Intelligent

a. Tentukan beberapa alternatif penentuan guru penerima umrah. Pada penentuan alternatif penentuan guru penerima umrah penulis memilih 3 contoh kasus kecil yaitu :

Tabel 2. Alternatif Guru

\begin{tabular}{|l|l|}
\hline Alternatif & Keterangan \\
\hline G1 & Guru 1 \\
\hline G2 & Guru 2 \\
\hline G3 & Guru 3 \\
\hline
\end{tabular}

b. Tentukan beberapa kriteria Penentuan Guru Penerima Umrah

Tabel 3. Kriteria

\begin{tabular}{|l|l|}
\hline Kriteria & Keterangan \\
\hline K1 & Hafal Al-Quran \\
\hline K2 & Masa Kerja \\
\hline K3 & Loyalitas \\
\hline K4 & Menejemen Kelas \\
\hline
\end{tabular}

c. Tentukan bobot kriteria penentuan guru penerima umrah

1. Guru I
a. Hafal Al-Quran Sangat Hafal
b. Masa Kerja
Tahun
c. Loyalitas
Cukup Loyalitas
d. Menejemen Kelas
$=$ Dapat Menangani
$: \mathrm{K} 1=$
(Sangat Baik)
$\mathrm{K} 2=10$
(Baik)
:K3 =
(Cukup Baik)
:K4
(Baik)

2. Guru II
a. Hafal Al-Quran:K1 = Sangat Hafal (Sangat Baik)
b. Masa Kerja : K2 = 5 Tahun (Cukup Baik)
c. Loyalitas Loyalitas
$: \mathrm{K} 3=$ (Baik)
d. Menejemen Kelas $=$ Dapat (Baik)
:K4
Menangani

3. Guru III
a. Hafal Al-Quran:K1= Hafal (Baik)
b. Masa Kerja
Tahun
$: \mathrm{K} 2=3$
c. Loyalitas :K3 = Cukup Loyalitas (Cukup Baik)
d. Menejemen Kelas:K4 = Tidak Dapat Menangani (Kurang)

Tabel 4. Nilai Kriteria dan Bobot Prefrensi

\begin{tabular}{|c|c|c|c|}
\hline Kriteria & ment & Nilai & Bobot \\
\hline Hafal Al-Qura & $n=$ & $50 \%$ & 6 \\
\hline Masa Kerja & $\sqrt{3 x}$ & $30 \%$ & 3 \\
\hline Loyalitas & & $20 \%$ & 2 \\
\hline Menejemen K & elas & $10 \%$ & 1 \\
\hline
\end{tabular}
ditentukan bobot-bobotnya. Pada bobot terdiri dari lima bilangan fuzzy, yaitu sangat rendah $(S R)$, rendah $(R)$, sedang $(S)$, tinggi $(T)$, dan sangat tinggi (ST) seperti terlihat pada gambar 1 berikut:

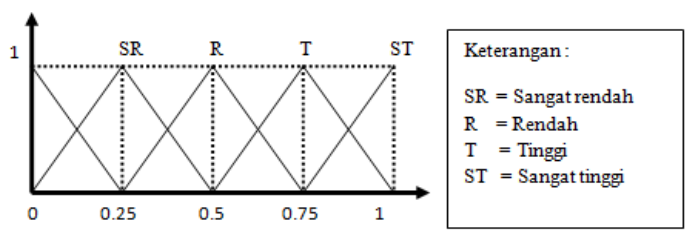

Gambar 1. Bilangan Analytical Hierarchy Process

Tabel 5. Bobot

\begin{tabular}{|l|l|l|}
\hline Kriteria & Bilangan AHP & Bobot \\
\hline K1 & Sangat Tinggi (ST) & 1 \\
\hline K2 & Tinggi (T) & 0,75 \\
\hline K3 & Rendah(R) & 0,5 \\
\hline K4 & Sangat Rendah(SR) & 0.25 \\
\hline
\end{tabular}


Berikut adalah uraian bobot-bobot dari kriteria yang ditentukan:

\section{a. Bobot Hafal Al-Quran (K1)}

Tabel 6. Bobot Hafal Al-Quran

\begin{tabular}{|l|l|l|}
\hline K1 & Bilangan Fuzzy & Bobot \\
\hline Sangat Hafal & Sangat Baik (SB) & 1 \\
\hline Hafal & Baik (B) & 0.75 \\
\hline Cukup Hafal & Cukup Baik (CB) & 0.5 \\
\hline Tidak Hafal & Kurang (K) & 0.25 \\
\hline
\end{tabular}

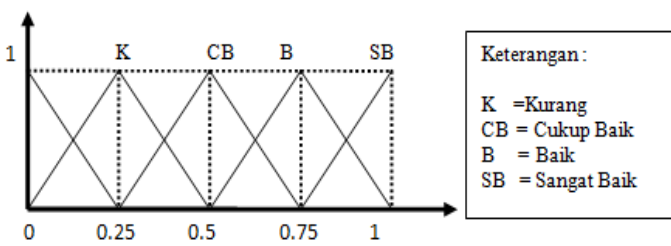

Gambar 2. Bilangan Fuzzy Untuk Bobot

b. Masa Kerja Hafal Al-Quran

Tabel 7. Masa Kerja

\begin{tabular}{|l|l|l|}
\hline K2 & Bilangan Fuzzy & Bobot \\
\hline 30 Thn -20Thn & Sangat Baik (SB) & 1 \\
\hline 20Thn - 10Thn & Baik (B) & 0,75 \\
\hline 10Thn - 5Thn & Cukup Baik (CB) & 0,5 \\
\hline
\end{tabular}

e. Manajemen Kelas

Tabel 9.Manajemen Kelas

\begin{tabular}{|lc|c|c|}
\hline K4 & $\begin{array}{l}\text { Bilangan } \\
\text { Fuzzy }\end{array}$ & Bobot \\
\hline $\begin{array}{l}\text { Sangat Dapat } \\
\text { Menangani }\end{array}$ & $\begin{array}{c}\text { Sangat } \\
\text { Baik (SB) }\end{array}$ & 1 \\
\hline \multicolumn{2}{|l|}{ Dapat Menagani } & Baik (Baik) & 0.75 \\
\hline $\begin{array}{l}\text { Cukup Dapat } \\
\text { Menagani }\end{array}$ & $\begin{array}{c}\text { Cukup Baik } \\
\text { (CB) }\end{array}$ & 0.5 \\
\hline $\begin{array}{l}\text { Tidak Dapat } \\
\text { Menangani }\end{array}$ & Kurang (K) & 0,25 \\
\hline
\end{tabular}

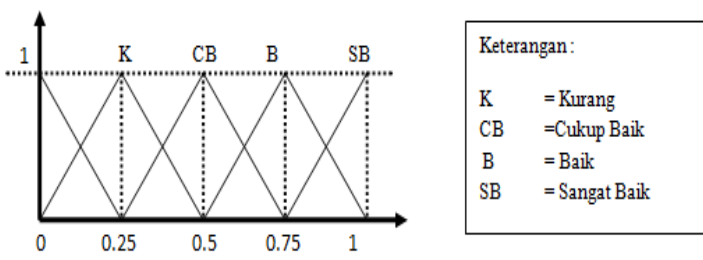

Gambar 5. Bilangan Fuzzy Untuk Managemen Kelas

Dari bobot diatas maka kita dapat menentukan bobot dari penentuan guru penerima umrah adalah sebagai berikut :

1. PEG I
a. Hafal Al-Quran $\quad=1$
b. Masa Kerja $\quad=0,75$
c. Loyalitas $\quad=0,5$
d. Managemen Kelas $=0.75$

2. PEG II
a. Hafal Al-Quran
$=1$

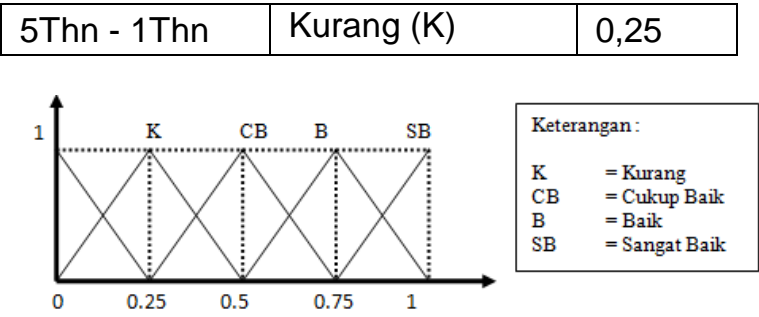

Gambar 3. Bilangan Fuzzy Untuk Masa

\section{c. Loyalitas}

Tabel 8. Ioyalitas

\begin{tabular}{|l|l|l|}
\hline K3 & Bilangan Fuzzy & Bobot \\
\hline Sangat Loyalitas & Sangat Baik (SB) & 1 \\
\hline Loyalitas & Baik (Baik) & 0.75 \\
\hline Cukup Loyalitas & Cukup Baik (CB) & 0.5 \\
\hline Tidak Loyalitas & Kurang (K) & 0,25 \\
\hline
\end{tabular}

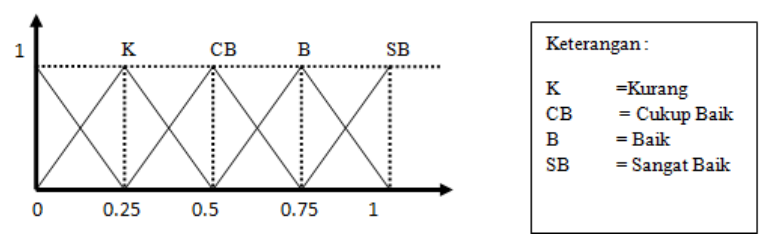

Gambar 4 Bilangan Fuzzy Untuk Loyalitas

$$
\begin{array}{ll}
\text { b. } \text { Masa Kerja } & =0,5 \\
\text { c. } \text { Loyalitas } & =0,75
\end{array}
$$

3. PEG III
a. Hafal Al-Quran
$=0,75$
b. Masa Kerja
$=0,25$
c. Loyalitas
$=0.5$
d. Managemen Kelas
$=0.25$

\subsubsection{Tahap Modelling}

Pada tahap modelling (pemodelan), penulis memilih model pendekatannya adalah Analytical Hierarchy Process. Pada tahap ini ada beberapa hal yang harus diperhatikan yaitu: Mendefinisikan masalah dan menentukan solusi yang diinginkan, lalu menyusun hirarki dari permasalahan yang dihadapi.

1. Gambarkan Hierarchy keputusan Dalam Hierarchy keputusan ini terdapat objek yang akan dibahas, kriteria dan alternatif. Berikut ini adalah gambar dari Hierarchy keputusan.

1. Tujuan atau Objek yang akan (Menilai guru-guru)

2. Kriteria (Hafal Al-Quran Masa Kerja, Loyalitas, Menejemen Kelas).

3. Alternatif (Nama-nama Guru yang akan dipilih). 


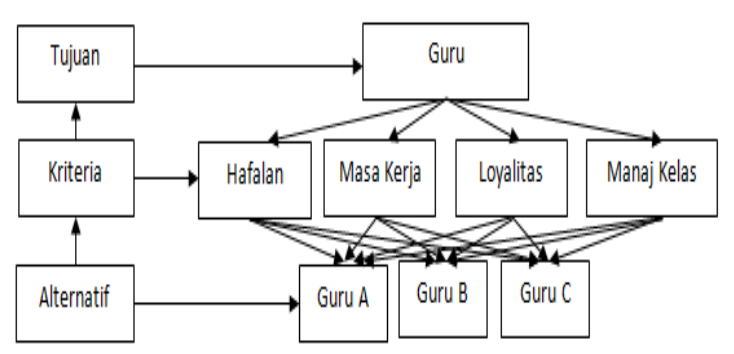

Gambar 6 : Hierarchy tujuan proses penentuan guru penerima umrah

2. Menentukan prioritas kriteria

a. Membuat matriks perbandingan krtiteria

Tabel 10. Matriks perbandingan berpasangan

\begin{tabular}{|l|c|c|c|c|}
\hline & K1 & K2 & K3 & K4 \\
\hline
\end{tabular}

b. Membuat matriks nilai Kriteria

\begin{tabular}{|c|c|c|c|c|}
\hline K1 & 1 & 2 & 3 & 6 \\
\hline K2 & 0,5 & 1 & 2 & 3 \\
\hline K3 & 0,33 & 0,5 & 1 & 2 \\
\hline K4 & 0,17 & 0,33 & 0,5 & 1 \\
\hline Jumlah & 2 & 3,83 & 6,5 & 12 \\
\hline
\end{tabular}

Angka 1 pada baris $\mathrm{K} 1$ kolom $\mathrm{K} 1$ menggambarkan tingkat yang sama antara kriteria Hafal Al-Quran dengan Hafal Al-Quran, sedangkan angka 2 pada baris $\mathrm{K} 1$ kolom $\mathrm{K} 2$ menunjukkan bahwa masa kerja (MKJ) sedikit lebih penting dibandingkan dengan kriteria Hafal AlQuran. Angka 0.5 pada baris K2 kolom K1 merupakan hasil perhitungan 1/nilai pada kolom K2 (2).Angka-angka yang lain diperoleh dengan cara yang sama.

Tabel 11. Matriks Nilai Keriteria

\begin{tabular}{|l|l|c|c|c|c|c|}
\hline & \multicolumn{1}{|c|}{ K1 } & K2 & K3 & K4 & $\begin{array}{c}\text { Jum } \\
\text { lah }\end{array}$ & $\begin{array}{c}\text { Prio } \\
\text { ritas }\end{array}$ \\
\hline K1 & 0,5 & 0,52 & 0,46 & 0,5 & 1,98 & 0,49 \\
\hline K2 & 0,25 & 0,26 & 0,30 & 0,25 & 1,06 & 0,27 \\
\hline K3 & 0,17 & 0,13 & 0,15 & 0,17 & 0,62 & 0,16 \\
\hline K4 & 0,09 & 0,09 & 0,08 & 0,08 & 0,34 & 0,09 \\
\hline
\end{tabular}

Nilai 0.5 pada baris $\mathrm{K} 1$ kolom $\mathrm{K} 1$ tabel 11 diperoleh dari nilai baris $\mathrm{K} 1$ kolom $\mathrm{K} 1$ tabel 4.10 dibagi dengan jumlah nilai pada kolom K1 tabel 4.10, Nilai kolom jumlah pada tabel 11 diperoleh dari penjumlahan pada setiap barisnya. Untuk baris pertama, nilai 1.98 merupakan hasil penjumlahan dari $0.5+0.52+0.46+0$, Nilai pada kolom prioritas diperoleh dari nilai

Tabel 12. Matriks penjumlahan setiap baris

\begin{tabular}{|l|l|l|l|l|l|}
\hline & K1 & K2 & K3 & K4 & Jumlah \\
\hline K1 & 0,49 & 0,54 & 0,48 & 0,54 & 2,05 \\
\hline K2 & 0,25 & 0,27 & 0,32 & 0,27 & 1,11 \\
\hline K3 & 0,16 & 0,14 & 0,16 & 0,18 & 0,64 \\
\hline K4 & 0,08 & 0,08 & 0,08 & 0,09 & 0,33 \\
\hline
\end{tabular}

Nilai 0.49 pada baris K1 kolom K1 tabel 12 diperoleh dari prioritas baris $\mathrm{K} 1$ tabel 11 (0.49) dikalikan nilai baris $\mathrm{K} 1$ kolom $\mathrm{K} 1$ pada tabel 4.10 . Kolom jumlah pada tabel 12 diperoleh dengan menjumlahkan nilai pada masing-masing baris pada tabel tersebut. Misalnya nilai 2.05 merupakan penjumlahan dari $0.49+0.54+0.48+0.54$.

d. Penghitungan rasio konsistensi

Penghitungan ini digunakan untuk pada kolom jumlah dibagi dengan jumlah kriteria, dalam hal ini jumlah kriteria adalah 4.

c. Membuat matriks penjumlahan setiap baris Matriks ini dibuat dengan mengalikan nilai prioritas pada tabel 11 dengan matriks perbandccccingan berpasangan tabel 10 . Hasil perhitungan disajikan dalam tabel 12

memastikan bahwa nilai rasio konsistensi $(\mathrm{CR})<=0.1$. Jika ternyata nilai CR lebih besar dari 0.1 maka matriks perbandingan bepasangan harus diperbaiki. Untuk menghitung rasio konsistensi, maka dibuat tabel berikut ini:

Tabel 13. Perhitungan rasio konsistensi

\begin{tabular}{|l|l|l|l|}
\hline & $\begin{array}{l}\text { Jumlah } \\
\text { Perbaris }\end{array}$ & Prioritas & Hasil \\
\hline K1 & 2,05 & 0,49 & 2,47 \\
\hline K2 & 1,11 & 0,27 & 1,33 \\
\hline K3 & 0,64 & 0,16 & 0,78 \\
\hline K4 & 0,33 & 0,09 & 0,43 \\
\hline
\end{tabular}

Kolom jumlah per baris diperoleh dari kolom jumlah pada table 4.12, Sedangkan kolom prioritas diperoleh dari kolom 
prioritas pada tabel 4.11. Dari tabel 4.13 diperoleh nilai-nilai sebagai berikut:

Jumlah (jumlahan dari nilai-nilai hasil pada tabel 4.13) = 5,01

$\mathrm{n}$ (jumlah kriteria) $=4$

$\lambda$ maks (jumlah/n) $=5,01 / 4$

$$
=1.25
$$

$\mathrm{Cl}((\lambda$ maks $-\mathrm{n}) / \mathrm{n})=(1.25-4) / 4$

$=-0,69 / 4$

$=-0.17$

CR $(\mathrm{Cl} / \mathrm{IR}($ lihat tabel 3.1) $)=-0.17 / 0.90$

$=-0.19$

Oleh karena $\mathrm{CR}<0.1$, maka rasio konsistensi dari perhitungan tersebut dapat diterima.

3. Menentukan prioritas subkriteria. Perhitungan subkriteria dilakukan terhadap sub-sub dari semua kriteria. Dalam hal ini terdapat 4 kriteria yang berarti akan ada 4 perhitungan subkriteria.

Menghitung prioritas subkriteria dari kriteria Hafal Al-Quran Guru. a. Membuat matriks perbandingan berpasangan Pada tahap ini dilakukan penilaian perbandingan antara satu kriteria dengan kriteria yang lain. Hasil penilaian dapat dilihat pada tabel 14 .

Tabel 14. Matriks perbandingan berpasangan Kriteria Hafal Al-Quran

\begin{tabular}{|l|c|c|c|c|}
\hline & Kurang & $\begin{array}{c}\text { Cukup } \\
\text { Baik }\end{array}$ & Baik & $\begin{array}{c}\text { Sangat } \\
\text { Baik }\end{array}$ \\
\hline Kurang & 1 & 0,75 & 0,5 & 0,25 \\
\hline Cukup Baik & 1,33 & 1 & 0,75 & 0,5 \\
\hline Baik & 2 & 1,33 & 1 & 0,75 \\
\hline Sangat Baik & 4 & 2 & 1,33 & 1 \\
\hline Jumlah & 8,33 & 5,08 & 3,58 & 2,5 \\
\hline
\end{tabular}

b.Membuat matriks nilai kriteria

Matriks ini diperoleh dengan cara sebagai berikut:

Nilai baris kolom baru = Nilai baris kolom lama ( Tabel 14) / jumlah dari masingmasing kolom ( Tabel 14 )Hasil perhitungan dapat dilihat pada table 15 Berikut :

Tabel 15. Matriks Nilai Keriteria Hafal Al-Quran

\begin{tabular}{|l|c|c|c|c|c|c|c|}
\hline & K & CB & B & SB & Jlh & Prioritas & $\begin{array}{c}\text { Prioritas } \\
\text { Subkriteria }\end{array}$ \\
\hline K & 0,12 & 0,15 & 0,14 & 0,1 & 0,51 & 0,13 & 0,32 \\
\hline CB & 0,16 & 0,19 & 0,20 & 0,2 & 0,75 & 0,19 & 0,46 \\
\hline B & 0,24 & 0,26 & 0,28 & 0,3 & 1,08 & 0,27 & 0,66 \\
\hline SB & 0,48 & 0,39 & 0,37 & 0,4 & 1,64 & 0,41 & 1 \\
\hline
\end{tabular}

nilai 0.51 merupakan hasil penjumlahan dari

Nilai 0.12 pada baris kriteria besar kolom kriteria Hafal Al-Quran tabel 15 diperoleh dari nilai baris kriteria besar kolom kriteria Hafal AlQuran dibagi jumlah nilai pada kolom kriteria Hafal Al-Quran tabel 14 Nilai kolom jumlah pada tabel 4.15 diperoleh dari penjumlahan pada setiap barisnya. Untuk baris pertama,
$0.12+0.16+0.24+0,48$ Nilai pada kolom prioritas diperoleh dari nilai pada kolom jumlah dibagi dengan 4. Nilai pada kolom prioritas subkriteria diperoleh dari nilai prioritas pada baris tersebut dibagi dengan nilai tertinggi pada kolom priorotas.

c. Membuat matriks penjumlahan setiap baris

Tabel 16. Matriks penjumlahan setiap baris Kriteria Hafal Al-Quran

\begin{tabular}{|l|l|l|l|l|l|}
\hline & K & CB & B & SB & Jumlah \\
\hline K & 0,13 & 0,14 & 0,14 & 0,10 & 0,51 \\
\hline CB & 0,17 & 0,19 & 0,20 & 0,21 & 0,77 \\
\hline B & 0,26 & 0,25 & 0,27 & 0,31 & 1,09 \\
\hline SB & 0,52 & 0,38 & 0,36 & 0,41 & 1,67 \\
\hline
\end{tabular}

Nilai 0.13 pada baris kriteria besar kolom kriteria Hafal Al-Quran tabel 16 diperoleh dari prioritas baris kriteria Hafal Al-Quran table 15 (0.13) dikalikan nilai baris kriteria besar kolom kriteria tes intelegensi pada tabel 14.Kolom jumlah pada tabel 4.16 diperoleh dengan menjumlahkan nilai pada masing-masing baris pada tabel tersebut. Misalnya nilai 0.51 merupakan penjumlahan dari0.13+0.14+0.14+0,10

d. Penghitungan rasio konsistensi

Penghitungan ini digunakan untuk memastikan bahwa nilai rasio konsistensi $(C R)<=0.1$. Jika ternyata nilai CR lebih besar dari 0.1 maka matriks perbandingan bepasangan harus 
diperbaiki. Untuk menghitung rasio konsistensi, maka dibuat tabel berikut ini:

Tabel 17. Perhitungan rasio konsistensi

\begin{tabular}{|c|l|l|l|}
\hline & $\begin{array}{l}\text { Jumlah } \\
\text { Perbaris }\end{array}$ & Prioritas & Hasil \\
\hline K & 0,51 & 0,13 & 0,64 \\
\hline CB & 0,77 & 0,19 & 0,96 \\
\hline B & 1,09 & 0,27 & 1,36 \\
\hline SB & 1,67 & 0,41 & 2,08 \\
\hline
\end{tabular}

Kolom jumlah per baris diperoleh dari kolom jumlah pada tabel 16, sedangkan kolom prioritas diperoleh dari kolom prioritas pada tabel 15 Dari tabel 4.16 diperoleh nilai-nilai sebagai berikut:

Jumlah (jumlahan dari nilai-nilai hasil pada tabel 17$)=5,04$

$\mathrm{n}$ (jumlah kriteria) $=4$

$\lambda$ maks (jumlah/n) $=5,04 / 4=1.26$

$\mathrm{Cl}((\lambda$ maks- $n) / n)=(1.26-4) / 4=-2.74 / 4$

$=-0.69$

$\mathrm{CR}(\mathrm{Cl} / \mathrm{IR}($ lihat tabel 3.1) $)=-0.69 / 0.90$

$=-0.77$

Oleh karena $\mathrm{CR}<0.1$, maka rasio konsistensi dari perhitungan tersebut dapat diterima.

\subsubsection{Choice}

Prioritas hasil perhitungan pada langkah 1 dan langkah 2 kemudian dituangkan dalam matriks hasil. Hasilnya tampak seperti tabel di bawah ini :

Tabel 18. Matriks hasil

\begin{tabular}{|c|c|c|c|}
\hline $\begin{array}{c}\text { Hafal Al- } \\
\text { Quran }\end{array}$ & $\begin{array}{c}\text { Masa } \\
\text { Kerja }\end{array}$ & Loyalitas & $\begin{array}{c}\text { Manajemen } \\
\text { Kelas }\end{array}$ \\
\hline 0,49 & 0,27 & 0,16 & 0,09 \\
\hline $\begin{array}{c}\text { Sangat } \\
\text { Baik }\end{array}$ & $\begin{array}{c}\text { Sangat } \\
\text { Baik }\end{array}$ & $\begin{array}{c}\text { Sangat } \\
\text { Baik }\end{array}$ & $\begin{array}{c}\text { Sangat } \\
\text { Baik }\end{array}$ \\
\hline 1 & 1 & 1 & 1 \\
\hline Baik & Baik & Baik & Baik \\
\hline 0,66 & 0,66 & 0,66 & 0,66 \\
\hline $\begin{array}{c}\text { Cukup } \\
\text { Baik }\end{array}$ & $\begin{array}{c}\text { Cukup } \\
\text { Baik }\end{array}$ & $\begin{array}{c}\text { Cukup } \\
\text { Baik }\end{array}$ & Cukup Baik \\
\hline 0,46 & 0,46 & 0,46 & 0,46 \\
\hline Kurang & Kurang & Kurang & Kurang \\
\hline 0,32 & 0,32 & 0,32 & 0,32 \\
\hline
\end{tabular}

Tabel 19. Nilai Guru

\begin{tabular}{|c|l|l|l|l|}
\hline & $\begin{array}{l}\text { Hafal } \\
\text { Al- } \\
\text { Quran }\end{array}$ & $\begin{array}{l}\text { Masa } \\
\text { Kerja }\end{array}$ & Loyalitas & $\begin{array}{l}\text { Manaje } \\
\text { men } \\
\text { Kelas }\end{array}$ \\
\hline $\begin{array}{c}\text { Guru } \\
1\end{array}$ & $\begin{array}{l}\text { Sangat } \\
\text { Baik }\end{array}$ & Baik & $\begin{array}{l}\text { Cukup } \\
\text { Baik }\end{array}$ & Baik \\
\hline $\begin{array}{c}\text { Guru } \\
2\end{array}$ & $\begin{array}{l}\text { Sangat } \\
\text { Baik }\end{array}$ & $\begin{array}{l}\text { Cukup } \\
\text { Baik }\end{array}$ & Baik & Baik \\
\hline $\begin{array}{c}\text { Guru } \\
3\end{array}$ & Baik & Kurang & $\begin{array}{l}\text { Cukup } \\
\text { Baik }\end{array}$ & Kurang \\
\hline
\end{tabular}

Tabel 20. Hasil akhir

\begin{tabular}{|c|l|l|l|l|l|}
\hline & $\begin{array}{l}\text { Hafal } \\
\text { Al- } \\
\text { Quran }\end{array}$ & $\begin{array}{l}\text { Masa } \\
\text { Kerja }\end{array}$ & $\begin{array}{l}\text { Loya } \\
\text { litas }\end{array}$ & $\begin{array}{l}\text { Manaje } \\
\text { men } \\
\text { Kelas }\end{array}$ & Total \\
\hline $\begin{array}{c}\text { Guru } \\
1\end{array}$ & 0,49 & 0,18 & 0,07 & 0,06 & 0,8 \\
\hline $\begin{array}{c}\text { Guru } \\
2\end{array}$ & 0,49 & 0,12 & 0,10 & 0,06 & 0,77 \\
\hline $\begin{array}{c}\text { Guru } \\
3\end{array}$ & 0,32 & 0,09 & 0,07 & 0,03 & 0,51 \\
\hline
\end{tabular}

Nilai 0,49 pada kolom Hafal Al-Quran baris Guru 1 diperoleh dari nilai guru Guru 1 untuk Hafal Al-Quran, yaitu sangat baik dengan prioritas 1 dikalikan dengan prioritas Hafal AlQuran sebesar 0,49.

Kolom total pada table 20 diperoleh dari penjumlahan pada masing-masing barisnya.Nilai total inilah yang dipakai sebagai dasar untuk merangking prestasi guru. Semakin besar nilainya, guru tersebut akan semakin berprestasi.

\section{KESIMPULAN DAN SARAN}

Dari hasil pemgujian metode yang dilakukan terhadap penelitian ini maka dapat ditarik beberapa kesimpulan yang terkait dengan proses penelitian maupun dengan isi dari penelitian itu sendiri.

1. Harus terlebih dahulu menentukan bobotbobot kriteria guru penerima umrah dengan metode Analytical Hierarchy Process.

2. Dengan kriteria yang ada dan juga nilai pembobotan yang benar dan proses dilakukan dengan transaksi maka hasilnya akan dapat lebih optimal dalam menentukan kelayakan guru yang akan ikut umrah dan hasilnya akan adil yang akan dapat menjadi motivasi bagi guru yang kainnya yang ingin umrah dan secara tidak langsung akan menambah loyalitas guru terhadap institusinya.

\section{DAFTAR PUSTAKA}

[1]. Andri Kristanto. "Perancangan Sistem Informasi dan Aplikasinya". Gava Media, Yogyakarta, 2008

[2]. Jogiyanto. "Analisis dan Desain Sistem Informasi" Penerbit Andi, Yogyakarta, 2005

[3]. Widjajanto, "Sistem Informasi Akuntansi", Erlangga, PT Gelora Aksara Pratama, Jakarta, 2008

[4]. Kusrini, "Konsep dan Aplikasi Sistem Pendukung Keputusan", Penerbit Andi Offset, Yogyakarta, 2007

[5]. Turban, E., dkk, "Decicion Support Systems and Intelligent Systems", Andi Offset, 2005 
[6]. Yuni Sugiarti, "Analisis \& Perancangan UML (Unified Modeling Language) Generated VB.6", Graha IImu, Yogyakarta. 2013

[7]. K. Puspita dan P. H.Putra, Penerapan Metode Simple Additive Weighting (SAW) Dalam Menentukan Pendirian Lokasi Gramedia Di Sumatera Utara. Seminar Nasional Teknologi Informasi Dan Multimedia, ISSN : 2302-3805, 2015

[8]. Rosnani Ginting. Sistem Pendukung Keputusan, Medan: USU Press,2014

[9]. Iskandar Z Nasibu (2009). "Theory AHP (Analytic Hierarchy Process) and used decision support system". Journal Pelangi Ilmu Volume 2, 34-35

[10]. T. Limbong. Implementasi Metode Simple Additive Weighting (SAW) Untuk Pemilihan Pekerjaan Bidang Informatika. SNIKOM 2013 ICT System Security, 2013.

[11]. PT. Hijrah Haromain",Panduan Haji dan Umrah 